\title{
Asthma Treatment: Role of Metabolism from a Double-blind Randomized Control Trial
}

\author{
Tarun Saxena ${ }^{1 *}$, Sanjay Patidar ${ }^{2}$, Manjari Saxena ${ }^{1}$ and Azeema Bhabrawala ${ }^{1}$ \\ ${ }^{1}$ Mittal Hospital and Research Center, Pushkar Road, Ajmer, India; ${ }^{2}$ Ministry of Health and Family Welfare, Government of India
}

\begin{abstract}
Background and objectives: The role of metabolism (basal metabolic rate (BMR)) in asthma remains dubious. Seasonal variations are reported in both BMR and asthma, with the former increasing in winter and decreasing in summer. Correlation between metabolism and asthma treatment is not obvious in the literature; therefore, it was planned to assess role of substances which alter metabolism in managing asthma.
\end{abstract}

Methods: This was a randomized double-blind active control trial, in which 400 confirmed asthma cases were divided into two groups (group 1 (control) and group 2 (study)), with group 2 further subdivided into two (subgroups 2A and 2B). The study period was from January to December 2016. During attack, group 2A was given kitchen spices (cloves, bay leaf, black pepper; substance A) and 2B was given cool substances (rose petal jam; substance B). The control group was given inhaled levosalbutamol. Symptoms and peak expiratory flow rate (PEFR) were recorded. Improvement was suggested by reduction in symptoms and improvement in PEFR. Review of symptoms was done at 24 and $72 \mathrm{~h}$ and of PEFR at $72 \mathrm{~h}$ after the therapy. Statistical significance of differences between group 1 and 2A and 2B was calculated by the chi-square test by using SPSS 20 software.

Results: Exacerbations were found in February (season: winter), March (spring), August (rainy) and October (autumn). In February and March, the response was significant with substance $A(p<0.001)$, but substance $B$ had poor response. In August and October, the response was significant with substance B $(p<0.001)$, and substance A had insignificant response.

Conclusions: Substances which increase BMR are helpful in winters and high metabolic state of the body, and conversely. Change in metabolism possibly effects heat and water losing/preserving effect of the body, including related to the respiratory tract (thermoregulation), and lessens inflammation in the respiratory tract.

Introduction

Incidences of bronchial asthma are mounting. There are multiple risk factors that have been found to be associated with asthma, ${ }^{1-5}$ and the role of metabolism in asthma is known to be complex. However, the correlation between metabolism and asthma treatment is less clearly described in the literature. A few studies have shown high basal metabolic rate (BMR), or metabolism, in asth-

Keywords: Asthma; Metabolism; Thermoregulation; Inflammation.

Abbreviations: BMR, basal metabolic rate; PEFR, peak expiratory flow rate.

Received: August 24, 2017; Accepted: October 30, 2017

${ }^{*}$ Correspondence to: Tarun Saxena, Mittal Hospital, E-196, Shastri Nagar, Ajmer, Rajasthan, India. E-mail: yogdiab@gmail.com

How to cite this article: Saxena T, Patidar S, Saxena M, Bhabrawala A. Asthma Treatment: Role of Metabolism from a Double-Blind Randomized Control Trial. Exploratory Research and Hypothesis in Medicine 2018;3(1):4-11. doi: 10.14218/ ERHM.2017.00030. matic patients, while others have found that obesity and asthma are associated with each other. ${ }^{6,7}$

Seasonal variations in asthma and BMR have also been reported. Some studies have depicted a higher incidence of asthma during cold weather, ${ }^{8-11}$ while others have suggested a higher incidence in summer and humid environment. ${ }^{12,13}$ According to Ayurveda, the BMR/metabolism of each cell/systemic changes across different seasons; during winter, the BMR increases and the body preserves heat, ${ }^{14-16}$ on the contrary, during summer, the BMR decreases and the body releases heat. ${ }^{14,17,18}$ Various kitchen spices, such as cloves, ${ }^{19,20}$ have been associated with an increase in BMR, while substances like rose petal jam have been found to be associated with decrease in BMR. ${ }^{21,22}$

To assess whether seasonal changes in asthma and metabolism are interrelated in this study, various substances that affect metabolism were administered. Therefore, the study was planned to see the effect of kitchen spices/rose petal jam on bronchial asthma treatment. 
Table 1. General examination

\begin{tabular}{llllll}
\hline Group & Age in years, mean & Sex & BMI in $\mathbf{~ g} / \mathbf{m}^{2}$, mean & Pulse rate, mean & Respiratory rate, mean \\
\hline Group 1, $n=200$ & 37 & $\begin{array}{l}\text { Male (45\%) } \\
\text { Female (55\%) }\end{array}$ & 23.1 & 80 & 14 \\
Subgroup 2A, $n=100$ & 39 & $\begin{array}{l}\text { Male (48\%) } \\
\text { Female (52\%) }\end{array}$ & 22.8 & 82 & 14 \\
Subgroup 2B, $n=100$ & 38 & $\begin{array}{l}\text { Male (49\%) } \\
\text { Female (51\%) }\end{array}$ & 22.9 & 78 & 15 \\
$p$-value & $>0.05$ & $>0.05$ & $>0.05$ & $>0.05$ & $>0.05$ \\
\hline
\end{tabular}

Methods

\section{Study design}

This study was a randomized double-blind, interventional, parallel group, active control trial (CTRI/2016/12/007589), and was conducted in the Department of Internal Medicine and the Department of Yoga and Ayurveda. Patients came from the city and nearby villages encompassing an area of 20-25 kilometers and representing a population of $2,000,000$.

\section{Case selection, study period and study methods}

Arbitrarily, a sample of 400 confirmed cases of bronchial asthma regularly attending to the hospital and presenting mild asthma symptoms during that prior 2 years were selected for the study. Informed written consent was obtained from each participant upon study enrollment and approval of the institutional ethical committee was awarded. Initial diagnosis was based on FEV1, forced expiratory volume in one second; of $<80 \%$ and reversibility (increase in FEV1 $>12 \%$ after $20 \mathrm{~m}$ of two levosalbutamol puffs).

Patients having a history of thyroid disorders, smoking, ischemic heart disease, hypertension, diabetes, requirement for oxygen therapy, moderate to severe symptoms of asthma, chronic respiratory infections, anemia and/or working in industries were excluded. The included cases were randomly divided into 2 groups, with group $1(n=200)$ representing the controls and group 2 representing the interventional group $(n=200)$. Group 2 was then subdivided randomly into group $2 \mathrm{~A}(n=100)$ and group 2B $(n=100)$.

The age range of the selected cases was $15-45$ years-old, and the study population included both males and females. The patients were studied from January 2016 to December 2016. The symptoms and PEFR, Peak Expiratory Flow Rate) were recorded by a specific technician in the hospital and checked by a consultant on that same day. The following parameters were considered in each case (monthly): symptoms and PEFR; exposure history to any aeroallergen (pollens or flowers) or festival allergen (smoke, paint); occupational exposure; history or presence of viral respiratory infections; and, exposure to various environmental conditions.

A record of environmental factors (air temperature, humidity, air velocity, presence of any dust storm) throughout the 12-month period was obtained from the meteorological department. A record of viral and bacterial respiratory infections, and epidemics was obtained from the Chief Medical Health Officer's office and the hospital record.

\section{Symptom scoring}

A normalized pattern was used. Four symptoms were included: cough; breathlessness; wheezing; and, chest heaviness. Each symptom was counted as one. For the attack, a symptom score of $>2$ with reduction in PEFR 15-20\% was considered as an 'attack'. The attack rate was calculated monthly by taking the number of attacks each month and dividing by the total number of cases.

\section{Intervention}

The intervention was given during the high attack rate period, when $>50 \%$ of subjects had an attack. Group $2 \mathrm{~A}$ was given substance A, which produces warmth inside the body (hot substances) and consisted of a mixed powder of kitchen spices, specifically two cloves (Syzgium aromaticum), 1 tejpatta leaf (Indian bay leaves) and 2 black pepper corns (Piper nigrum), given twice daily. Group 2B was given substance $\mathrm{B}$, which produces coolness inside the body (cool substances) and consisted of 1 Tablespoon of gulkand (sweet preserve of rose petals, known as petal jam) and 2 teaspoons of syrup of Brahmi (Bacopa monnieri) in a glass of water mixed with $10 \mathrm{~g}$ of Mishri (crystallized sugar lump), given twice daily. Comparison was done between each subgroup and the control group, which was given inhaled levosalbutamol $(50 \mathrm{mcg}$ by two puffs thrice daily) at the time of attack. The process was repeated during each attack throughout the 12-month study period. The cases were strictly monitored over a course of $72 \mathrm{~h}$ to detect any worsening of symptoms.

\section{Outcome measurement}

Review of the symptoms of asthma cough, wheezing, chest heaviness and breathlessness at 24 and $72 \mathrm{~h}$ and of PEFR at $72 \mathrm{~h}$ after the therapy, and comparisons with the control group were done at the same time.

\section{Statistical analysis}

The collected data were entered in a Microsoft Excel sheet. Statistical analysis was carried out by using SPSS 20.0 statistical software. The appropriate test of significance was applied (chi-square test).

\section{Results}

The baseline features of group 1 and subgroups $2 \mathrm{~A}$ and $2 \mathrm{~B}$ were 
Table 2. Allergen exposure data for January 2016 through December 2016

\begin{tabular}{|c|c|c|c|c|c|c|c|c|c|c|c|c|}
\hline Month & Jan & Feb & Mar & Apr & May & Jun & July & Aug & Sep & Oct & Nov & Dec \\
\hline Respiratory infections viral & $23 \%$ & $66 \%$ & $31 \%$ & $16 \%$ & $6 \%$ & $8 \%$ & $14 \%$ & $74 \%$ & $11 \%$ & $23 \%$ & $23 \%$ & $28 \%$ \\
\hline Allergens/aeroallergen pollens/flowers & $37 \%$ & $38 \%$ & $41 \%$ & $40 \%$ & $23 \%$ & $22 \%$ & $25 \%$ & $27 \%$ & $22 \%$ & $28 \%$ & $33 \%$ & $22 \%$ \\
\hline Festival colors & $5 \%$ & $5 \%$ & $49 \%$ & $9 \%$ & $11 \%$ & $14 \%$ & $13 \%$ & $13 \%$ & $44 \%$ & $43 \%$ & $10 \%$ & $2 \%$ \\
\hline Cracker smoke & $5 \%$ & $4 \%$ & $3 \%$ & $2 \%$ & $3 \%$ & $6 \%$ & $1 \%$ & $3 \%$ & $22 \%$ & $40 \%$ & $42 \%$ & $7 \%$ \\
\hline \multicolumn{13}{|l|}{ Environmental factors } \\
\hline (a) Dust storm & no & no & no & no & yes & yes & no & no & no & no & no & no \\
\hline (b) Environmental temperature $(\min / \max ){ }^{\circ} \mathrm{C}$ & $5 / 18$ & $8 / 19$ & $13 / 27$ & $28 / 36$ & $34 / 43$ & $34 / 44$ & $31 / 37$ & $29 / 36$ & $30 / 36$ & $22 / 32$ & $22 / 27$ & $12 / 26$ \\
\hline (c) Air velocity km/h & 12 & 10 & 14 & 22 & 47 & 43 & 11 & 10 & 11 & 15 & 10 & 11 \\
\hline (d) Humidity \% & $16 \%$ & $19 \%$ & $23 \%$ & $24 \%$ & $45 \%$ & $43 \%$ & $54 \%$ & $21 \%$ & $33 \%$ & $22 \%$ & $27 \%$ & $11 \%$ \\
\hline Occupational factor/pollutant change & no & no & no & no & no & no & no & no & no & no & no & no \\
\hline
\end{tabular}

comparable (Table 1). There were various allergens during the different months (Table 2). The maximum asthma exacerbations occurred in February, March, August and October (Table 3). Irrespective of allergens during February and March, a significant response (both of symptoms and PEFR) to the intervention was found for subgroup 2A compared to group $1(p<0.001)$. During August and October, a significant response (both of symptoms and PEFR) to the intervention was found for subgroup 2B compared to group 1 ( $p<0.001)$ (Tables 4 and 5; Fig. 1).

\section{Discussion}

Worldwide, incidence of asthma is on the rise. The role of metabolism in asthma remains unclear. A few studies have shown high BMR (metabolism) in asthma patients. Seasonal variations in asthma and BMR are also reported. Still, a clear relationship between asthma and metabolism remains to be established. Therefore, this study was planned to observe seasonal variations of asthma and the effect of various substances affecting metabolism on the clinical profile of asthma.

As already detailed in the Methods section, the study was done in a medical institute, with 400 confirmed cases of asthma, and lasted from January 2016 to December 2016. The cases were randomly divided into two groups, including group 1 (control, $n$ $=200$ ) and group 2 (study). The group 2 was further subdivided into group $2 \mathrm{~A}(n=100)$ and group $2 \mathrm{~B}(n=100)$. Throughout the 12 -month study period, the symptoms and PEFR were recorded. Allergen exposure history was also recorded. Attack/exacerbation was considered by an increase in the symptoms and a reduction in PEFR. The intervention was given during the high attack rate period, when $>50 \%$ subjects had an attack, and consisted of giving substance A to group 2A (mixed powder of kitchen spices) and substance B to group 2B (combination of substances like gulkand or preserve of rose petals, known as petal jam). Substance A is a mixture which increases BMR (hot substances). ${ }^{10,11}$ Substance $\mathrm{B}$ is a combination of substances which reduce BMR (cool substances). ${ }^{12}$ Results in subgroups $2 \mathrm{~A}$ and $2 \mathrm{~B}$ were compared at 24 and $72 \mathrm{~h}$ for symptoms and PEFR with group 1 , which had been given inhaled levosalbutamol.

As already detailed in the Results section, in the present study, four periods of high attack rate were found, one in February (winter), the second in March (spring), the third in August (rainy season), and the fourth in October (onset of winter or autumn). During the rest of the year, there was not much increase in attack rate. The attack rate was insignificant during peak summer (May and June) and peak winter (December and January). During February and March, a significant response (both symptoms and PEFR) to the intervention was found for group 2A compared to group 1. In August and October, a significant response (both symptoms and PEFR) to the intervention was found for group $2 \mathrm{~B}$ as compared to group 1 .

Thus, during winter and spring months, the response was better with substances that increase metabolic rate and produce warmth inside the body (such as substance A), similar to findings in other studies, ${ }^{12,13}$ and during summer and autumn, the response was better with substances that reduce metabolic rate and give a cooling effect to the body (such as substance B). ${ }^{14,15}$

On the contrary, during the winter months and spring, the response to substance B was poor; however, this was found to be effective during the rainy season and autumn. Similarly, substance A was ineffective during the rainy season and autumn, but was found to be effective during winter and spring. Environmental temperature is low during the winter and spring and high during the rainy season and autumn. The metabolic rate is high in low environmental temperature and low in high environmental temperature (Fig. 2). This suggests that response to a particular substance (A or B) is season- or body metabolism-dependent and not a direct effect nor immunity-dependent. It, therefore, indicates a possible role of metabolism in management of asthma. It also suggests that metabolism in spring continues to be that of winter metabolism, and in autumn continues to follow summer metabolism.

BMR is the minimum cellular activity required for survival in a particular season. For an individual, the BMR primarily depends on height, weight, age and sex, but it changes with season. BMR increases in cold temperature and decreases in summer (i.e. basal activity of each cell necessary for its survival changes according to season). ${ }^{14-16}$ This is also depicted in Ayurveda. ${ }^{23,24}$ As shown in Figure 2, the hypothalamus senses environmental temperature and sets BMR/metabolism accordingly. ${ }^{25}$ Metabolism of the body sets a particular temperature/ season after exposure over a period of time, and not instantly.

The high attack rate in our study was attributed to different allergens in different months. Besides other factors in February $(66 \%$ viral infections) and August (74\% viral infections), the maximum contribution was accounted for by viral infections; in March and October, despite exposure to coloring agents, smoke and crackers ( $30-35 \%$ contribution), the maximum effect was of change in tem- 
Table 3. Symptoms and PEFR before intervention, for January-December 2016

\begin{tabular}{|c|c|c|c|c|c|c|}
\hline \multirow{2}{*}{ Month } & \multirow{2}{*}{ Group } & \multicolumn{5}{|c|}{ Symptoms } \\
\hline & & Cough & Breathlessness & Wheezing & Chest heaviness & PEFR reduction \\
\hline \multirow[t]{3}{*}{ January } & 1 & $16 \%$ & $22 \%$ & $23 \%$ & $12 \%$ & $14 \%$ \\
\hline & $2 \mathrm{~A}$ & $18 \%$ & $22 \%$ & $21 \%$ & $13 \%$ & $14 \%$ \\
\hline & $2 B$ & $17 \%$ & $22 \%$ & $21 \%$ & $11 \%$ & $12 \%$ \\
\hline \multirow[t]{3}{*}{ February } & 1 & $93 \%$ & $95 \%$ & $92 \%$ & $75 \%$ & $90 \%$ \\
\hline & $2 \mathrm{~A}$ & $93 \%$ & $96 \%$ & $94 \%$ & $71 \%$ & $92 \%$ \\
\hline & $2 \mathrm{~B}$ & $95 \%$ & $91 \%$ & $91 \%$ & $73 \%$ & $91 \%$ \\
\hline \multirow[t]{3}{*}{ March } & 1 & $94 \%$ & $93 \%$ & $94 \%$ & $72 \%$ & $93 \%$ \\
\hline & $2 \mathrm{~A}$ & $94 \%$ & $92 \%$ & $94 \%$ & $73 \%$ & $95 \%$ \\
\hline & $2 B$ & $94 \%$ & $93 \%$ & $94 \%$ & $71 \%$ & $95 \%$ \\
\hline \multirow[t]{3}{*}{ April } & 1 & $24 \%$ & $21 \%$ & $17 \%$ & $18 \%$ & $16 \%$ \\
\hline & $2 \mathrm{~A}$ & $23 \%$ & $20 \%$ & $16 \%$ & $18 \%$ & $16 \%$ \\
\hline & $2 B$ & $24 \%$ & $21 \%$ & $16 \%$ & $18 \%$ & $16 \%$ \\
\hline \multirow[t]{3}{*}{ May } & 1 & $12 \%$ & $11 \%$ & $8 \%$ & $9 \%$ & $10 \%$ \\
\hline & $2 \mathrm{~A}$ & $12 \%$ & $10 \%$ & $12 \%$ & $11 \%$ & $10 \%$ \\
\hline & $2 B$ & $12 \%$ & $10 \%$ & $9 \%$ & $9 \%$ & $10 \%$ \\
\hline \multirow[t]{3}{*}{ June } & 1 & $14 \%$ & $10 \%$ & $8 \%$ & $8 \%$ & $12 \%$ \\
\hline & $2 \mathrm{~A}$ & $16 \%$ & $11 \%$ & $9 \%$ & $8 \%$ & $11 \%$ \\
\hline & $2 \mathrm{~B}$ & $15 \%$ & $11 \%$ & $8 \%$ & $8 \%$ & $11 \%$ \\
\hline \multirow[t]{3}{*}{ July } & 1 & $42 \%$ & $35 \%$ & $28 \%$ & $21 \%$ & $32 \%$ \\
\hline & $2 \mathrm{~A}$ & $40 \%$ & $36 \%$ & $28 \%$ & $21 \%$ & $32 \%$ \\
\hline & $2 \mathrm{~B}$ & $40 \%$ & $36 \%$ & $28 \%$ & $21 \%$ & $32 \%$ \\
\hline \multirow[t]{3}{*}{ August } & 1 & $95 \%$ & $94 \%$ & $95 \%$ & $83 \%$ & $95 \%$ \\
\hline & $2 \mathrm{~A}$ & $96 \%$ & $95 \%$ & $95 \%$ & $77 \%$ & $95 \%$ \\
\hline & $2 B$ & $95 \%$ & $96 \%$ & $95 \%$ & $77 \%$ & $95 \%$ \\
\hline \multirow[t]{3}{*}{ September } & 1 & $13 \%$ & $14 \%$ & $17 \%$ & $9 \%$ & $13 \%$ \\
\hline & $2 \mathrm{~A}$ & $15 \%$ & $14 \%$ & $15 \%$ & $9 \%$ & $12 \%$ \\
\hline & $2 B$ & $13 \%$ & $14 \%$ & $16 \%$ & $9 \%$ & $12 \%$ \\
\hline \multirow[t]{3}{*}{ October } & 1 & $96 \%$ & $96 \%$ & $94 \%$ & $70 \%$ & $92 \%$ \\
\hline & $2 \mathrm{~A}$ & $95 \%$ & $95 \%$ & $96 \%$ & $72 \%$ & $93 \%$ \\
\hline & $2 B$ & $96 \%$ & $95 \%$ & $93 \%$ & $70 \%$ & $93 \%$ \\
\hline \multirow[t]{3}{*}{ November } & 1 & $41 \%$ & $44 \%$ & $38 \%$ & $22 \%$ & $37 \%$ \\
\hline & $2 \mathrm{~A}$ & $43 \%$ & $38 \%$ & $39 \%$ & $21 \%$ & $38 \%$ \\
\hline & $2 \mathrm{~B}$ & $45 \%$ & $44 \%$ & $39 \%$ & $21 \%$ & $33 \%$ \\
\hline \multirow[t]{3}{*}{ December } & 1 & $22 \%$ & $18 \%$ & $16 \%$ & $12 \%$ & $17 \%$ \\
\hline & $2 \mathrm{~A}$ & $22 \%$ & $18 \%$ & $18 \%$ & $11 \%$ & $16 \%$ \\
\hline & $2 B$ & $24 \%$ & $19 \%$ & $18 \%$ & $12 \%$ & $16 \%$ \\
\hline
\end{tabular}

perature, with almost $100 \%$ of cases being exposed to the external environmental temperature. In this part of the country there is a change of season in March (spring), that starts off as an increase in the environmental temperature $\left(19-27^{\circ} \mathrm{C}\right.$ maximum temperature from February to March), but in September and October (autumn) it starts off as a decline in the environmental temperature (30-22 ${ }^{\circ} \mathrm{C}$ minimum temperature from September to October). This increase and decrease in environmental temperature opposes the ex- 
Table 4. Symptoms and PEFR after intervention, for January-December 2016

\begin{tabular}{|c|c|c|c|c|c|c|c|c|}
\hline & February & & March & & August & & October & \\
\hline Symptoms and PEFR group 1 & After $24 \mathrm{~h}$ & After $72 \mathrm{~h}$ & After $24 \mathrm{~h}$ & After $72 \mathrm{~h}$ & After $24 \mathrm{~h}$ & After $72 \mathrm{~h}$ & After $24 \mathrm{~h}$ & After $72 \mathrm{~h}$ \\
\hline Improvement in $>2$ symptoms & $60 \%$ & $84 \%$ & $68 \%$ & $82 \%$ & $64 \%$ & $67 \%$ & $70 \%$ & $84 \%$ \\
\hline Improvement in PEFR & & $82 \%$ & & $80 \%$ & & $64 \%$ & & $82 \%$ \\
\hline \multicolumn{9}{|l|}{ Symptoms and PEFR group $2 \mathrm{~A}$} \\
\hline Improvement in $>2$ symptoms & $78 \%$ & $96 \%$ & $84 \%$ & $97 \%$ & $14 \%$ & $17 \%$ & $12 \%$ & $19 \%$ \\
\hline Improvement in PEFR & & $94 \%$ & & $96 \%$ & & $15 \%$ & & $17 \%$ \\
\hline \multicolumn{9}{|l|}{ Symptoms and PEFR group 2B } \\
\hline Improvement in $>2$ symptoms & $12 \%$ & $16 \%$ & $15 \%$ & $16 \%$ & $86 \%$ & $96 \%$ & $88 \%$ & $97 \%$ \\
\hline Improvement in PEFR & & $15 \%$ & & $14 \%$ & & $94 \%$ & & $95 \%$ \\
\hline
\end{tabular}

Abbreviation: PEFR, peak expiratory flow rate.

isting metabolism of the body in March, in which a state of existent high metabolism is opposed by rising environmental temperature which tries to bring down the metabolism. During October, a state of existent low metabolism is opposed by declining environmental temperature which tries to raise the metabolism; therefore, the asthma attack rate is high during this period.

Table 5. Significance level

\begin{tabular}{|c|c|c|c|c|}
\hline & February & March & August & October \\
\hline Groups Symptoms & $24 \mathrm{~h} / 72 \mathrm{~h}$ & $24 \mathrm{~h} / 72 \mathrm{~h}$ & $24 \mathrm{~h} / 72 \mathrm{~h}$ & $24 \mathrm{~h} / 72 \mathrm{~h}$ \\
\hline \multicolumn{5}{|l|}{1 vs $2 \mathrm{~A}$} \\
\hline$p$-value & $0.003 /<0.001$ & $<0.001 /<0.001$ & $<0.001 /<0.001$ & $<0.001 /<0.001$ \\
\hline Odds ratio & $0.219 / 0.191$ & $0.141 / 0.098$ & $9.913 / 11.61$ & $22.382 / 26.21$ \\
\hline \multicolumn{5}{|l|}{1 vs $2 \mathrm{~B}$} \\
\hline$p$-value & $<0.001 /<0.001$ & $<0.001 /<0.001$ & $<0.001<0.001$ & $<0.001 /<0.001$ \\
\hline Odds ratio & $27.56 / 32.94$ & $23.91 / 26.46$ & $0.085 / 0.082$ & $0.162 / 0.150$ \\
\hline \multicolumn{5}{|l|}{$2 \mathrm{~A}$ vs $2 \mathrm{~B}$} \\
\hline$p$-value & $<0.001 /<0.001$ & $<0.001 /<0.001$ & $<0.001 /<0.001$ & $<0.001 /<0.001$ \\
\hline Odds ratio & 126.0/137.2 & 169.7/174.3 & $0.009 / 0.008$ & $0.007 / 0.007$ \\
\hline \multicolumn{5}{|l|}{1 vs 2} \\
\hline$p$-value & $<0.001 /<0.001$ & $<0.001 /<0.001$ & $0.03 /<0.001$ & $<0.001 /<0.001$ \\
\hline Odds ratio & $4.12 / 4.16$ & $3.50 / 3.67$ & $1.56 / 1.62$ & $3.80 / 3.78$ \\
\hline \multicolumn{5}{|l|}{ PEFR } \\
\hline \multicolumn{5}{|l|}{1 vs $2 \mathrm{~A}$} \\
\hline$p$-value & $<0.001$ & $<0.001$ & $<0.001$ & $<0.001$ \\
\hline Odds ratio & 0.038 & 0.040 & 8.84 & 4.16 \\
\hline \multicolumn{5}{|l|}{1 vs 2B } \\
\hline$p$-value & 0.005 & $<0.001$ & $<0.001$ & $<0.001$ \\
\hline Odds ratio & 3.436 & 5.988 & 0.0993 & 0.449 \\
\hline \multicolumn{5}{|l|}{$2 \mathrm{~A}$ vs $2 \mathrm{~B}$} \\
\hline$p$-value & $<0.001$ & $<0.001$ & $<0.001$ & $<0.001$ \\
\hline Odds ratio & 88.71 & 147.42 & 0.011 & 0.011 \\
\hline \multicolumn{5}{|l|}{1 vs 2} \\
\hline$p$-value & $<0.001$ & $<0.001$ & 0.053 & $<0.001$ \\
\hline Odds ratio & 3.8 & 3.27 & 1.484 & 3.57 \\
\hline
\end{tabular}




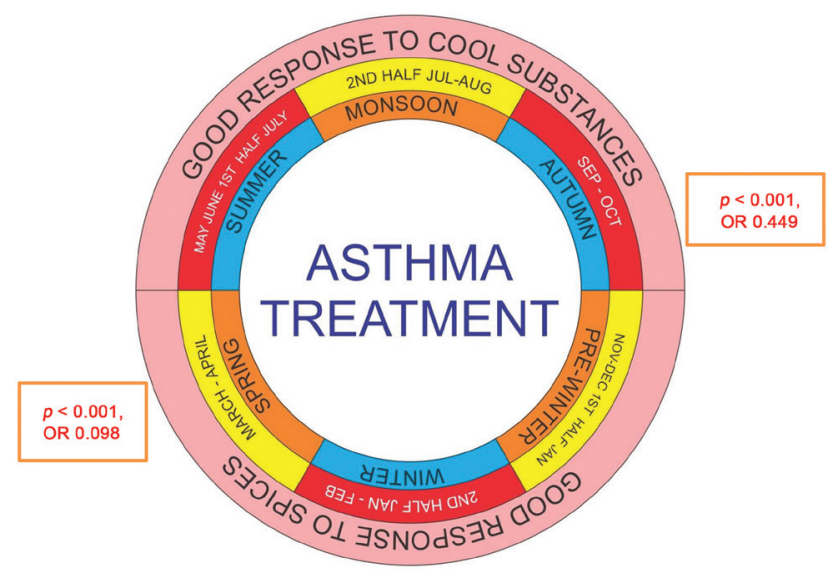

Fig. 1. Response to asthma symptoms. A good response to cool substances during state of low metabolism, and conversely, occurs.

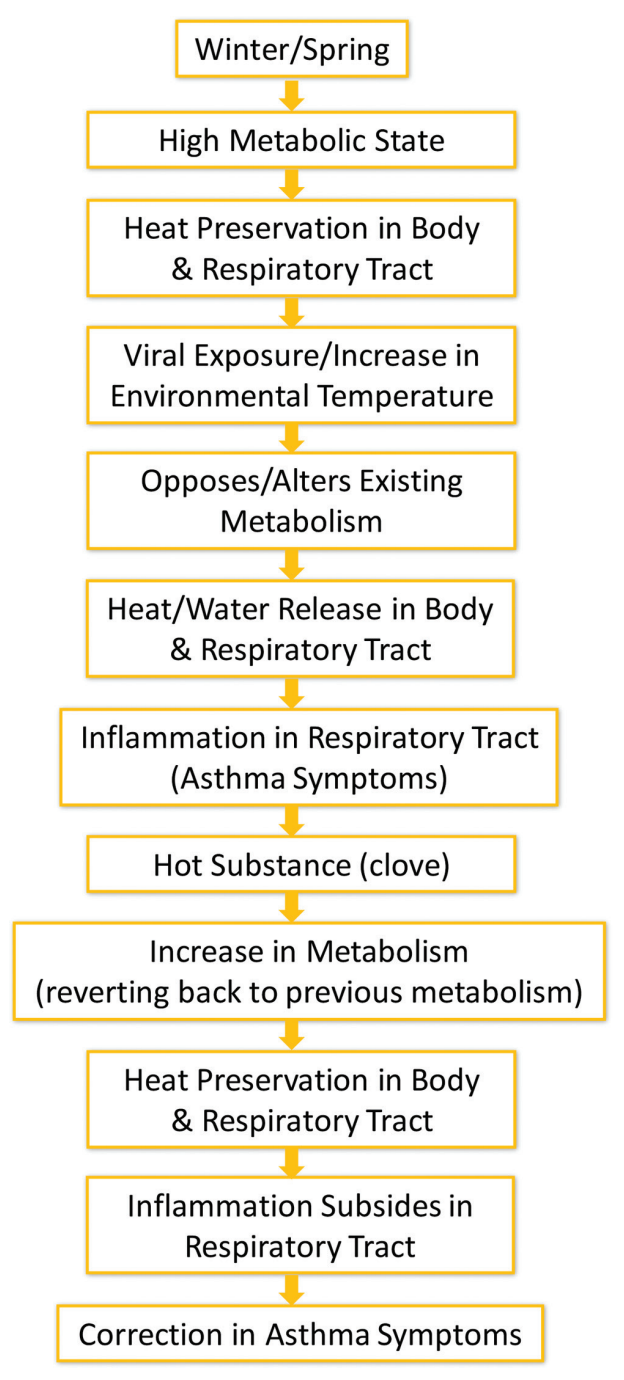

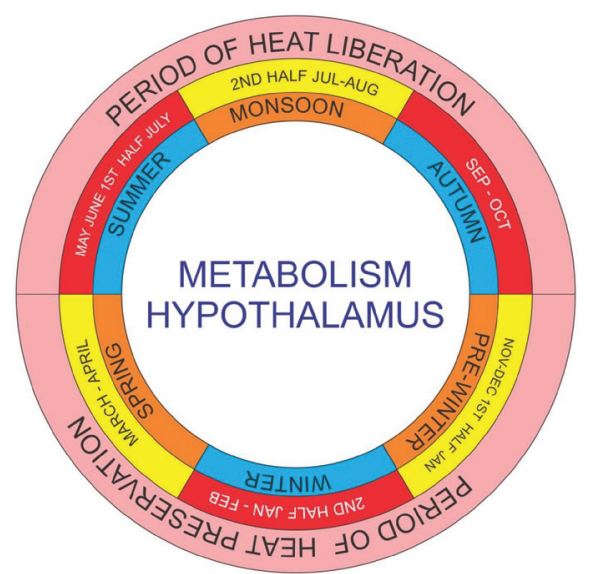

Fig. 2. State of metabolism during different months set by hypothalamus. The state of low metabolism in summer months and high metabolism in winter months.

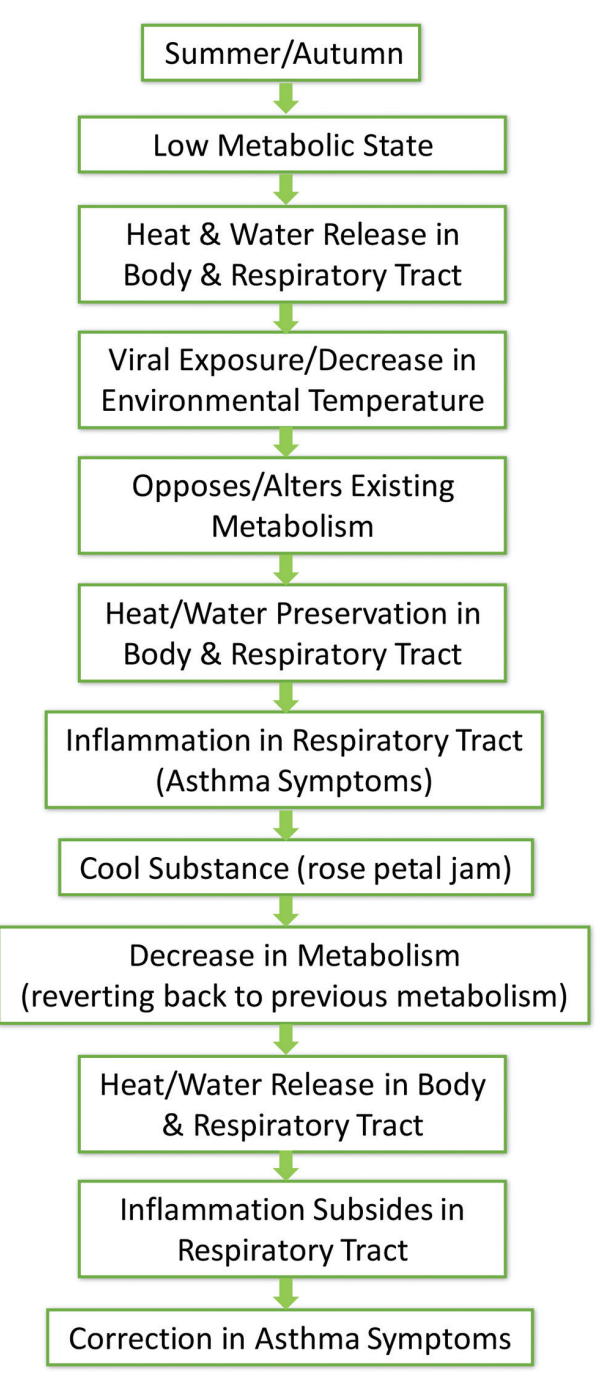

Fig. 3. Flow chart of the asthma/season changes. 
All allergens produce inflammation of respiratory mucosa, clinically presenting as cough wheezing, breathlessness and chest pain associated with reduction in PEFR. ${ }^{26,27}$ Correction in metabolism (i.e. metabolism suitable to particular season) possibly reduces inflammation in respiratory mucosa and, therefore, improves asthma symptoms. This is irrespective of allergen exposure, especially because attacks post-viral infection in February (66\%) and August (74\%) were quickly corrected by substance A and substance B respectively in environments suitable to the substance.

In summary, we found that metabolism of the body changes with environmental temperature and season. Specifically, in winter and spring, metabolism remains high and asthma symptoms respond well to substances which increase the metabolic rate, such as clove. In summer and autumn, metabolism remains low and asthma symptoms respond well to substances which reduce the metabolic rate, like rose petal jam.

The possible mechanism by which change in metabolism affects inflammation in the tracheobronchial tree seems to involve the respiratory tract, as one of the sites of heat and water release and thermoregulation in the body, ${ }^{28,29}$ and changes in heat release which affect inflammation in the respiratory tract. ${ }^{29,30}$ Changes in heat release or heat preservation are parallel to the heat-releasing or heat-saving mechanisms of the body. In low environmental temperature or the high metabolism state, ${ }^{14,15}$ heat preservation occurs throughout the body, including in the respiratory tract. This prevents inflammation in the respiratory tract. A sudden increase in external temperature (environmental or inhaled) gives impulses to the hypothalamus, opposite to the existing metabolism of heat preservation. There is a sudden slowdown of metabolism and release of heat throughout the body, including in the respiratory tract. This produces an inflammatory effect in the respiratory tract and nasal mucosa. ${ }^{31-33}$

By administering clove-like substances, metabolism is increased, correction of metabolism occurs and inflammation in the respiratory tract subsides, and vice versa. This is similar to a person wearing a warm jacket in a cold environment. The person is comfortable; however, if $\mathrm{s} / \mathrm{he}$ suddenly experiences heat due to sunlight $\mathrm{s} / \mathrm{he}$ will face uneasiness and will perspire. A similar uneasiness is present in the respiratory tract (both skin and respiratory tract are heat-releasing sites) and are associated with inflammation and asthma symptoms. Once s/he removes the jacket and comes back to the cold environment, $\mathrm{s} / \mathrm{he}$ becomes comfortable in a way that is suitable to body metabolism. Quick response, even at $24 \mathrm{~h}$, almost excludes all other possibilities of improvement, including modulation of immunity. In viral infection, though portal of entry is the respiratory tract, the virus produces systemic symptoms like fever, myalgia, exanthem and bronchospasm, which affect metabolism and therefore can be helped by substances favorable to seasonal metabolism (Fig. 3).

\section{Hypothesis and future research direction}

It is hypothesized that management of asthma is metabolismdependent. Hot substances like clove are helpful in regressing asthma symptoms in cold weather or high metabolic state, and cool substance like rose petal jam are helpful in mitigating asthma symptoms in warm weather or low metabolic state. Alteration in metabolism possibly affects heat/water losing/preserving effect of the body, including in the respiratory tract (thermoregulation) and reduces inflammation in the respiratory tract. Body and lungs function smoothly in a metabolic state which is most suitable to the environment. Further studies are required to elucidate the association of the BMR-increasing and -decreasing substances with seasonal changes in treatment of asthma.

\section{Conclusions}

Management of asthma is metabolism-dependent. It bears repeating, hot substances like clove are helpful in regressing asthma symptoms in cold weather or high metabolic state, and cool substance like rose petal jam are helpful in mitigating asthma symptoms in warm weather or low metabolic state. Alteration in metabolism possibly affects heat/water losing/preserving effect of the body, including in the respiratory tract (thermoregulation), and reduces inflammation in the respiratory tract. Body and lungs function smoothly in a metabolic state which is most suitable to the environment.

\section{Conflict of interest}

The authors have no conflict of interests related to this publication.

\section{Author contributions}

Study design (TS, SP), manuscript writing (TS, MS); data collection (SP, MS), data analysis (SP), counseling the patients (MS, $\mathrm{AB})$, collection and editing of references $(\mathrm{AB})$.

\section{References}

[1] Lister S, Sheppeard V, Morgan G, Corbett S, Kaldor J, Henry R. February asthma outbreaks in NSW; a case control study. Aust N Z J Public Health 2001;25(6):514-519. doi:10.1111/j.1467-842X.2001.tb00315.x.

[2] Murray CS, Poletti G, Kebadze T, Morris J, Woodcock A, Johnston $\mathrm{SL}$, et al. Study of modifiable risk factors for asthma exacerbations: virus infection and allergen exposure increase the risk of asthma hospitalization in children. Thorax 2006;61:376-382. doi:10.1136/ thx.2005.042523.

[3] Saxena T, Maheshwari S, Saxen M. Mild cool air- A risk factor for asthma exacerbations: Results of a retrospective study. JAPI 2011;59:624-628.

[4] Johnston NW, Johnston SL, Norman GR, Dai J, Sears MR. The September epidemic of asthma exacerbations. School children as disease vectors. J Allergy ClinImmunol 2006;117:557-562. doi:10.1016/j. jaci.2005.11.034.

[5] Murray CS, Simpson A, Custovic A. Allergens, viruses and asthma exacerbations. Proc Am ThoracSoc 2004;1:99-104. doi:10.1513/ pats. 2306027.

[6] Agha MA, El Wahsh RA. Basal metabolic rate in bronchial asthma and chronic obstructive pulmonary disease patients. Egypt J Chest Dis Tuberc 2013;62(1):39-44. doi:10.1016/j.ejcdt.2013.01.007.

[7] Grasemann H. Metabolic origin of childhood asthma. Mol Cell Pediatr 2015;2:6. doi:10.1186/s40348-015-0017-3.

[8] Chen WY, Horton DJ. Airways obstruction in asthmatics induced by body cooling. Scand J Respir Dis 1978;59(1):13-20.

[9] Zeitoun M, Wilk B, Matsuzaka A, KnOpfli BH, Wilson BA, Bar-Or O. Facial cooling enhances exercise-induced bronchoconstriction in asthmatic child. Medi sci sports Exerc 2004;36(5):767-771.

[10] Chen WY, Chai H. Airway cooling and nocturnal asthma. Chest 1982;81(6):675-680. doi:10.1378/chest.81.6.675.

[11] Rodriguez-Martinez F, Mascia AV, Mellins RB. The effect of environmental temperature on airway resistance in the asthmatic child. Pediatr Res 1973;7(7):627-631. doi:10.1203/00006450-19730700000005. 
[12] Khosravi M, Collins PB, Lin RL, Hayes D Jr, Smith JA, Lee LY. Breathing hot humid air induces airway irritation and cough in patients with allergic rhinitis. Respir Physiol Neurobiol 2014;198:13-19. doi:10.1016/j.resp.2014.03.013.

[13] Hayes D Jr, Collins PB, Khosravi M, Lin RL, Lee LY. Bronchoconstriction triggered by breathing hot humid air in patients with asthma: role of cholinergic reflex. Am J Respir Crit Care Med 2012;185(11):11901196. doi:10.1164/rccm.201201-00880C.

[14] van Ooijen AM, van Marken Lichtenbelt WD, van Steenhoven AA, Westerterp KR. Seasonal Changes in metabolic \& temperature responses in cold air in humans. Physiol Behav 2004;82(2-3):545-553. doi:10.1016/j.physbeh.2004.05.001.

[15] Van Ooijen AMJ, Van Marken Lichtenbelt WD, Westerterp KR. Individual differences in body temperature and the relation to energy expenditure: the influence of mild cold. J Them Biol 2001;26:455-459. doi:10.1016/S0306-4565(01)00060-2.

[16] Van Marken Lichtenbelt WD, Shrauen P, Van De Kerckhove S, Wester terp Platenga MS. Individual variation in body temperature and energy expenditure in response to mild cold. Am J physiol Endocrinol metab 2002;282:E1077-E1083. doi:10.1152/ajpendo.00020.2001.

[17] O'Cain CF, Dowling NB, Slutsky AS, Hensley MJ, Strohi KP, McFadden ER Jr, et al. Airway effect of respiratory heat loss in normal subjects. J Appl Physiol Respir Environ Exerc Physiol 1980;49(5):875-880. doi:10.1152/jappl.1980.49.5.875.

[18] Bates GP, Miller VS. Grahm P Bates and Veronica S Miller. Sweat rate and sodium loss during work in the heat. J Occup Med Toxicol 2008;3:4. doi:10.1186/1745-6673-3-4.

[19] Henry CJ, Emery B. Effect of spiced food on metabolic rate. Hum Nutr Clin Nutr 1986;40(2):165-168.

[20] Westerterp-Plantenga M, Diepvens K, Joosen AM, Bérubé-Parent S, Tremblay A. Metabolic effect of spices, teas and caffeine. Physiol Behav 2006;89(1):85-91. doi:10.1016/j.physbeh.2006.01.027.

[21] Rizvi MA, Ali SA. Medicinal flowers of Pakistan. Int J Adv Res 2016;4(2):1313-1341.
[22] Alagesaboopathi C. Ethnobotanical studies on useful plants of Sirumalai Hills of Eastern Ghats Dindigul District of Tamilnadu, Southern India. Int J Biosci 2012;2(2):77-84.

[23] Nathani N, Tiwari SK, Samaria JK. A critical study on Ritucharya and its relation with Tamaka Shwasa (Bronchial Asthma). Asian journal of Modern and Ayurvedic Medical Science 2012;1(1).

[24] Thakkar J, Chaudhari S, Sarkar PK. Ritucharya: Answer to the lifestyle disorders. Ayu 2011;32(4):466-471. doi:10.4103/0974-8520.96117.

[25] Boulant JA. Role of the preoptic-anterior hypothalamus in thermoregulation and fever. Clin Infect Dis 2000;31(suppl 5):S157-S161. doi:10.1086/317521.

[26] Pulmonary Ventilation- Functions of respiratory passageways. In: Guyton AC, Hall JE ed. Textbook of medical physiology. Philadelphia Saunders, 2006:479-480.

[27] Asthma-Diseases of the respiratory system. In: Harrison S, ed. Textbook of Internal Medicine, 19th edition. McGraw-Hill Professional, 2015:1669-1671.

[28] Walker JE, Wells RE Jr, Merrill EW. Heat and water exchange in respiratory tract. Am J Med 1961;30:259-267. doi:10.1016/00029343(61)90097-3.

[29] Robertshaw D. Mechanism for the control of respiratory heat loss in panting animals. J Appl Physiol 2006;101(2):664-668. doi:10.1152/ japplphysiol.01380.2005.

[30] Farley RD, Albazzaz MK, Patel KR. Role of cooling and drying in hyperventilation induced asthma. Thorax 1988;43(4):289-294. doi:10.1136/thx.43.4.289.

[31] Anderson SD, Schoeffel RE, Follet R, Perry CP, Daviskas E, Kendall M. Sensitivity to heat and water loss at rest and during exercise in asthmatic patients. Eur J Respir Dis 1982;63(5):459-471.

[32] Olsson P, Bende M. Influence of environmental temperature on nasal mucosa. Ann Otol Rhinol Laryngol 1985;94(2 Pt 1):153-155. doi:10.1177/000348948509400211.

[33] Naclerio RM, Bachert C, Baraniuk JN. Pathophysiology of nasal congestion. Int J Gen Med 2010;3:47-57. 